\title{
KONTRIBUSI MODEL PEMBELAJARAN PROJECT BASED LEARNING TERHADAP KEMAMPUAN BERPIKIR KRITIS MATEMATIS SISWA MADRASAH TSANAWIYAH
}

\author{
Rifqi Hidayat'1), Saerah²) \\ ${ }^{1)}$ Universitas Muhammadiyah Cirebon, Jl. Tuparev No.70, Cirebon; rifqi.math@gmail.com \\ 2)Universitas Muhammadiyah Cirebon, Jl. Tuparev No.70, Cirebon; saeraherra @gmail.com
}

\begin{abstract}
Penelitian ini mengkaji akan kemampuan berpikir kritis matematis siswa MTs setelah diterapkannya model pembelajaran project based learning pada pembelajaran matematika. Penelitian ini didasari oleh rendahnya kemampuan berpikir kritis matematis siswa MTs dan kurangnya keaktifan siswa MTs dalam pembelajaran matematika. Tujuan penelitian ini adalah untuk mengetahui perbedaan serta peningkatan kemampuan berpikir kritis matematis siswa yang pembelajarannya menggunakan model Project Based Learning dengan pembelajaran secara konvensional. Penelitian ini merupakan penelitian Quasi Experimental Design dengan bentuk Nonequivalent Control Group Design. Populasi dalam penelitian ini adalah seluruh siswa kelas VII MTs NU Putra 1 Buntet Pesantren tahun pelajaran 2014/2015. Sampel penelitian diambil dengan teknik purposive sampling yaitu sebanyak 32 siswa pada kelas VII C dengan penerapan model pembelajaran Project Based Learning dan sebanyak 30 siswa pada kelas VII A dengan pembelajaran secara konvensional. Instrumen yang digunakan dalam penelitian ini adalah tes kemampuan berpikir kritis matematis. Analisis data dilakukan secara kuantitatif dan kualitatif. Analisis kuantitatif dilakukan dengan menggunakan Independent Sample $t$-Test. Hasil penelitian menunjukkan bahwa: (1) Kemampuan berpikir kritis matematis siswa yang pembelajarannya menggunakan model pembelajaran Project Based Learning lebih baik daripada kemampuan berpikir kritis matematis siswa yang pembelajarannya secara konvensional; (2) Peningkatan kemampuan berpikir kritis matematis siswa yang pembelajarannya menggunakan penerapan model pembelajaran Project Based Learning lebih baik daripada peningkatan kemampuan berpikir kritis matematis siswa yang pembelajarannya secara konvensional.
\end{abstract}

Keywords : Project Based Learning, Kemampuan Berpikir Kritis Matematis.

\section{PENDAHULUAN}

Tujuan pendidikan pada dasarnya mengantarkan para siswa pada perubahanperubahan tingkah laku, baik intelektual, moral maupun sosial agar dapat hidup mandiri sebagai individu dan mahluk sosial, dari pernyataan tersebut menyiratkan arti pentingnya pembelajaran yang melibatkan peserta didik untuk turut serta secara aktif dalam proses belajar mengajar. Proses belajar mengajar merupakan interaksi antar guru dan peserta didik secara terencana, terarah, terprogram. Secara sederhana, proses belajar mengajar harus melahirkan perubahan yang berarti pada peserta didik. Perubahan ini dapat berupa kemampuan kognitif, psikomotor, ataupun afektif. Upaya mencapai tujuan tersebut, seorang guru berusaha meningkatkan profesinya sebagai tenaga pendidik, motivator, transformator, mediator, fasilisator dan sebagainya (Tafsir dkk, 2008: 15).

Kurikulum 2013 ini membawa beberapa implikasi, salah satunya dalam hal penggunaan pendekatan dan model pembelajaran yaitu "...pendekatan Saintific, Discovery Learning, Project Based Learning, Problem Based Learning, Inquiry Learning dan High Order Thinking Skills, dalam pembelajaran”. Penggunaan metode-metode tersebut memberikan kesempatan kepada siswa untuk kritis, kreatif dan aktif dalam proses pembelajaran. Tetapi, belum terbiasanya siswa dengan metode tersebut mengakibatkan "Proses pembelajaran siswa aktif memerlukan waktu yang lebih panjang 
dari proses pembelajaran penyampaian informasi karena peserta didik perlu latihan untuk melakukan pengamatan, menanya, asosiasi, menyaji dan komunikasi" (Kemdikbud , 2013: 4).

Mata pelajaran matematika merupakan salah satu mata pelajaran yang dapat digunakan untuk membangun cara berpikir siswa. Matematika merupakan salah satu bidang studi yang menduduki peranan penting dalam pendidikan, pelajaran matematika di sekolah tidak sekedar menekankan pada pemberian rumus-rumus melainkan juga mengajarkan siswa untuk dapat menyelesaikan berbagai masalah matematis yang berkaitan dengan kehidupan sehari-hari. Selain itu pelajaran matematika di sekolah diharapkan mampu membuat siswa memandang matematika sebagai sesuatu yang dapat dipahami merasakan matematika sebagai sesuatu yang berguna, dan meyakini usaha yang tekun dan ulet dalam mempelajari matematika akan membuahkan hasil.

Keaktifan peserta didik dalam proses pembelajaran merupakan salah satu indikator keberhasilan pembelajaran. Salah satu bagian penting yang mendukung keberhasilan proses pembelajaran adalah penggunaan model dan media pembelajaran yang tepat sesuai dengan tujuan dan materi pembelajaran. Penggunaan model dan media pembelajaran dalam proses belajar mengajar di samping memiliki daya tarik bagi peserta didik juga akan meningkatkan kualitas pembelajaran, baik kualitas proses maupun kualitas hasil. Hal tersebut sejalan dengan pernyataan Melvin (Tafsir, 2008: 17), yaitu: "yang saya dengar saya lupa; yang saya dengar dan lihat, saya sedikit ingat; yang saya dengar, lihat dan pertanyakan dengan orang lain saya mulai paham; yang saya dengar, lihat, bahas dan terapkan, saya mendapatkan pengetahuan dan keterampilan; yang saya ajarkan kepada orang lain saya kuasai”. Pernyataan tersebut menyiratkan arti pentingnya pembelajaran yang melibatkan peserta didik untuk turut serta secara aktif dalam proses belajar mengajar. Berbeda halnya dengan pembelajaran dalam kurikulum 2013, pembelajaran yang berlangsung di sekolah selama ini yang lebih banyak berpusat pada guru, kurang memberikan kesempatan siswa untuk lebih aktif dalam proses pembelajaran dan siswa lebih banyak pasif menerima informasi yang diberikan.

Pada laporan Trends in International Mathematics and Science Study TIMSS (2007), siswa Indonesia berada pada posisi 36 dari 49 negara yang disurvei. Prestasi Indonesia jauh dibawah negara-negara Asia lainnya, dengan rata-rata skor internasional 500 dan standar deviasi 100, nilai matematika Indonesia berada pada skor 397, dengan demikian nilai matematika Indonesia berada signifikan dibawah nilai rata-rata internasional.

Berpikir kritis merupakan salah satu proses berpikir tingkat tinggi yang dapat digunakan dalam pembentukan sistem konseptual siswa. Menurut Ennis (Hidayat, 2012: 17) menyatakan bahwa komponen kemampuan berpikir kritis dikenal dengan istilah keterampilan berpikir kritis dan berpikir kritis adalah cara berpikir reflektif yang masuk akal atau berdasarkan nalar yang difokuskan untuk menentukan apa yang harus diyakini dan dilakukan. Rendahnya kemampuan berpikir kritis juga diindikasikan dapat berimplikasi pada rendahnya prestasi siswa.

Berdasarkan pengamatan yang telah dilakukan peneliti di MTs Putra 1 Buntet Pesantren Kabupaten Cirebon keadaan yang hampir sama ditemukan, yaitu siswa merasa kesulitan dalam menyelesaikan soal-soal matematika yang diberikan, khususnya soalsoal berkategori sukar. Hal ini dibuktikan dengan nilai rata-rata Ujian Nasional yang masih rendah, yaitu untuk mata pelajaran matematika hanya berkisar 6,00. Kesulitan siswa disebabkan berbagai alasan misalnya tidak hafal rumus, salah menempatkan rumus, soal-soal latihan berbeda dengan contoh soal dan lupa dengan materi yang dipelajari sebelumnya. Indikasi yang mudah dilihat adalah hasil belajar siswa yang kurang maksimal dan masih ada yang mendapat nilai dibawah Kriteria Ketuntasan Minimal (KKM), yaitu 75. Beberapa faktor yang berkaitan dengan rendahnya hasil 
belajar siswa, yang paling utama adalah rendahnya aktivitas siswa untuk mengikuti pelajaran dengan baik dan bersungguhsungguh, siswa kurang dilibatkan secara aktif dalam pembelajaran, kurang menariknya guru dalam melakukan tugas mengajar, serta kurangnya kemampuan berpikir kritis matematis siswa. seseorang yang berpikir kritis matematis akan cenderung memiliki sikap yang positif terhadap matematika, sehingga akan berusaha menalar dan mencari strategi penyelesaian masalah matematika. Tantangan bagi guru adalah perlunya memahami tentang materi dan strategi pembelajaran. Peran guru dalam pembelajaran berpusat pada siswa bergeser dari semula sebagai pengajar menjadi fasilitator. Fasilisator adalah orang yang memberikan kemudahan-kemudahan, menyiapkan sarana-sarana belajar yang diperlukan siswa, seperti: guntingan koran, kamus dan sumber-sumber belajar lainnya (Kosasih, 2014: 43). Fakta di atas menunjukkan bahwa kurangnya perhatian terhadap kemampuan berpikir kritis dalam matematika beserta implikasinya, dengan demikian maka sangat diperlukan perhatian lebih pada kemampuan ini guna pembelajaran matematika saat ini.

Penggunaan model atau metode pembelajaran adalah salah satu aspek yang sangat penting dalam aktivitas pembelajaran, karena penggunaan model pembelajaran yang tepat dan sesuai dengan materi pembelajaran memiliki daya tarik bagi peserta didik. Sebagaimana yang dikemukakan Teguh (2009: 79), "Bangunlah ketertarikan dan ajaklah murid-murid anda menapaki perjalanan intelektual dalam proses-proses belajar mengajar yang anda pimpin dengan semangat yang jelas dan penuh kegembiraan dengan bersungguhsungguh dalam mencapai hasil yang baik dari hal-hal yang tadinya belum dicoba". Pernyataan tersebut menjelaskan bahwa proses pembelajaran harus dibuat dengan mudah sekaligus menyenangkan agar siswa tidak tertekan secara psikologis dan tidak merasa bosan terhadap suasana di kelas, serta apa yang diajarkan oleh gurunya. Salah satu model pembelajaran yang dapat digunakan untuk meningkatkan kemampuan berpikir kritis matematis siswa yaitu model pembelajaran Project Based Learning (PjBL). Project Based Learning yaitu model pembelajaran yang menggunakan proyek/kegiatan sebagai tujuannya (Kosasih, 2014; 96). Pembelajaran berbasis proyek memfokuskan pada aktivitas siswa yang berupa pengumpulan informasi dan pemanfaatannya, tetapi tetap terkait dengan Kompetensi Dasar (KD) dalam kurikulum (Kosasih, 2014: 96).

Kesulitan yang mungkin dihadapi oleh guru dalam menerapkan pembelajaran $\mathrm{PjBL}$ ini ialah, PjBL memerlukan tambahan sarana mungkin juga biaya, siswa juga belum terbiasanya dengan model pembelajaran yang menekankan kekritisan siswa dalam belajar matematika, mengakibatkan adanya kemungkinan siswa menghadapi jalan buntu dan kemungkinan lamanya waktu yang diperlukan untuk menemukan jawaban atas soal matematika dalam proses pembelajaran Project Based Learning (Kosasih, 2014: 97). Hal itu sebaiknya tidak perlu menjadi alasan untuk tidak terselenggaranya model pembelajaran tersebut karena ada sesuatu yang lebih berharga yakni siswa dapat berpikir rasional dan kritis dalam menggunakan prinsipprinsip dan dasar-dasar pengertian dalam menjawab pertanyaan seperti bagaimana dan mengapa (Kosasih, 2014: 5).

Berdasarkan latar belakang yang diuraikan di atas, maka rumusan masalah dalam penelitian ini adalah sebagai berikut:

1. Apakah kemampuan berpikir kritis matematis siswa yang pembelajarannya menggunakan model Project Based Learning lebih baik daripada siswa yang pembelajarannya secara konvensional?

2. Apakah peningkatan kemampuan berpikir kritis matematis siswa yang pembelajarannya menggunakan model Project Based Learning lebih baik daripada siswa yang pembelajarannya secara konvensional?

Untuk menjaga agar penelitian ini fokus pada masalah yang akan diteliti, maka peneliti membatasi hal-hal berikut:

1. Model Project Based Learning dalam penelitian ini sesuai dengan pendapatnya Kosasih (2014) yaitu model pembelajaran 
yang menggunakan proyek/kegiatan sebagai tujuannya, serta penelitian ini berbasis alat peraga sebagai produknya.

2. Indikator kemampuan berpikir kritis matematis dalam penelitian ini yaitu 3 dari 5 indikator yang dijelaskan Ennis (Hidayat, 2012), diantaranya: memberikan penjelasan sederhana, membangun keterampilan dasar dan mengatur strategi serta teknik.

\section{METODOLOGI PENELITIAN}

Penelitian ini menggunakan desain penelitian Quasi Experimental dengan bentuk Nonequivalent Control Group Design. Populasi dalam penelitian ini adalah seluruh siswa kelas VII MTs NU Putra 1 Buntet Pesantren Kabupaten Cirebon tahun pelajaran 2014/2015. Teknik sampling menggunakan teknik Sampling Purposive, tujuan dilakukan pengambilan sampel dengan teknik ini adalah agar penelitian dapat dilaksanakan secara efektif dan efisien terutama dalam hal pengawasan, kondisi subyek penelitian, waktu penelitian yang ditetapkan, kondisi tempat penelitian serta prosedur perijinan. Sampel penelitian yaitu 32 siswa kelas VII C sebagai kelas eksperimen yang diberi perlakukan menggunakan model Project Based Learning dan 30 siswa kelas VII A sebagai kelas kontrol yang pembelajarannya secara konvensional.

Instrumen yang digunakan untuk mengukur variabel-variabel dalam penelitian ini adalah, tes kemampuan berpikir kreatif matematis. Tes ini digunakan untuk mengukur kemampuan berpikir kritis matematis siswa MTs dalam bentuk uraian.

\section{HASIL DAN PEMBAHASAN}

Pembahasan hasil penelitian ini berdasarkan pada faktor-faktor yang diamati dan ditemukan dalam penelitian.

\section{Kemampuan Berpikir Kritis Matematis Siswa}

Kemampuan berpikir kritis matematis siswa dapat diketahui dari hasil pre-test dan post-test kelas ekpserimen dan kontrol. Gambaran hasil pre-test dan post-test kedua kelompok siswa disajikan pada tabel 1 berikut.

Tabel 1. Gambaran Umum Hasil Pre-test dan Post-test Kemampuan Berpikir Kritis Matematis

\begin{tabular}{|c|c|c|c|c|c|c|}
\hline $\begin{array}{c}\text { Da } \\
\text { ta }\end{array}$ & Kelas & $\mathbf{N}$ & $\begin{array}{c}\mathbf{M i} \\
\mathbf{n}\end{array}$ & $\begin{array}{l}\text { M } \\
\text { ax }\end{array}$ & $\begin{array}{l}\text { Me } \\
\text { an }\end{array}$ & $\begin{array}{c}\text { Std } \\
\text { Devia } \\
\text { tion }\end{array}$ \\
\hline $\begin{array}{c}P r \\
e-\end{array}$ & $\begin{array}{l}\text { Eksper } \\
\text { imen }\end{array}$ & $\begin{array}{l}3 \\
2\end{array}$ & $\begin{array}{c}6,6 \\
7\end{array}$ & $\begin{array}{l}25, \\
00\end{array}$ & $\begin{array}{l}15, \\
21\end{array}$ & 5,28 \\
\hline $\begin{array}{c}\text { tes } \\
t\end{array}$ & $\begin{array}{c}\text { Kontro } \\
1\end{array}$ & $\begin{array}{l}3 \\
0\end{array}$ & $\begin{array}{c}6,6 \\
7\end{array}$ & $\begin{array}{r}25, \\
00\end{array}$ & $\begin{array}{l}16, \\
00\end{array}$ & 4,34 \\
\hline $\begin{array}{l}\text { Po } \\
\text { st- }\end{array}$ & $\begin{array}{c}\text { Eksper } \\
\text { imen }\end{array}$ & $\begin{array}{l}3 \\
2\end{array}$ & $\begin{array}{l}65 \\
00\end{array}$ & $\begin{array}{l}95, \\
00\end{array}$ & $\begin{array}{l}82, \\
03\end{array}$ & 6,58 \\
\hline $\begin{array}{c}\text { tes } \\
t\end{array}$ & $\begin{array}{c}\text { Kontro } \\
1\end{array}$ & $\begin{array}{l}3 \\
0\end{array}$ & $\begin{array}{l}40, \\
00\end{array}$ & $\begin{array}{l}80, \\
00\end{array}$ & $\begin{array}{l}60, \\
83\end{array}$ & 7,78 \\
\hline
\end{tabular}

Berdasarkan tabel 1 di atas, diketahui nilai rerata pre-test kelas eksperimen sebesar 15,21 dan untuk kelas kontrol sebesar 16,00. Artinya kemampuan awal berpikir kritis matematis kedua kelas/kelompok siswa relatif sama. Sedangkan nilai rerata post-test kemampuan berpikir kritis matematis siswa kelas eksperimen mencapai 82,03 lebih tinggi daripada nilai rerata post-test siswa kelas kontrol, yaitu sebesar 60,83.

Guna membuktikan bahwa nilai posttest kemampuan berpikir kritis matematis siswa kelas eksperimen lebih baik daripada kelas kontrol dilakukan uji perbedaan rerata nilai post-test dengan menggunakan uji Independent Sample T-Test karena data nilai post-test berdistribusi normal dan homogen. Berikut rangkuman hasil uji perbedaan rerata skor post-test pada taraf signifikansi a $=0,05$. 
Tabel 2. Data Hasil Uji Perbedaan Rerata Skor Post-test Kemampuan Berpikir Kritis Matematis

\begin{tabular}{|c|c|c|c|c|c|c|}
\hline \multirow{2}{*}{\multicolumn{2}{|c|}{ Skor }} & \multicolumn{2}{|c|}{$\begin{array}{l}\text { Levene's } \\
\text { Test for } \\
\text { Equalit } \\
\text { y of } \\
\text { Varianc } \\
\text { es }\end{array}$} & \multicolumn{3}{|c|}{$\begin{array}{l}\text { t-test for } \\
\text { Equality of } \\
\text { Means }\end{array}$} \\
\hline & & $\mathrm{F}$ & $\begin{array}{c}\text { Sig } \\
.\end{array}$ & $\mathrm{t}$ & $\begin{array}{l}\mathrm{d} \\
\mathrm{f}\end{array}$ & $\begin{array}{l}\text { Sig. } \\
(1- \\
\text { taile } \\
\text { d) }\end{array}$ \\
\hline $\begin{array}{l}\text { Post_te } \\
\text { st }\end{array}$ & $\begin{array}{l}\text { Equal } \\
\text { varianc } \\
\text { es } \\
\text { assume } \\
\text { d }\end{array}$ & .355 & .553 & $\begin{array}{r}11.61 \\
0\end{array}$ & 60 & 0.000 \\
\hline
\end{tabular}

Berdasarkan tabel 2 di atas, hasil uji perbedaan rerata post-test diperoleh nilai sig.(1-tailed) adalah 0,000. Karena sig.(1tailed $)=0,000<0,05$ maka $\mathrm{H}_{0}$ ditolak. Artinya hipotesis diterima yaitu kemampuan berpikir kritis matematis siswa yang pembelajarannya menggunakan model Project Based Learning lebih baik daripada siswa yang pembelajarannya secara konvensional.

\section{Peningkatan Kemampuan Berpikir Kritis Matematis}

Peningkatan pemahaman konsep matematis siswa kelas ekpserimen dan kontrol dapat diketahui dari nilai $N$-gain. Gambaran umum hasil $N$-gain kedua kelompok siswa disajikan pada tabel berikut.

Tabel 3. Gambaran Umum Hasil Peningkatan Kemampuan Berpikir Kritis Matematis

\begin{tabular}{|c|c|c|c|c|c|c|}
\hline $\begin{array}{c}\text { Da } \\
\text { ta }\end{array}$ & Kelas & $\mathbf{N}$ & $\begin{array}{l}\text { M } \\
\text { in }\end{array}$ & $\begin{array}{l}\text { M } \\
\mathbf{a x}\end{array}$ & $\begin{array}{l}\mathrm{Me} \\
\text { an }\end{array}$ & $\begin{array}{c}\text { Std } \\
\text { Devia } \\
\text { tion }\end{array}$ \\
\hline \multirow{2}{*}{$\begin{array}{c}N- \\
g a i \\
n\end{array}$} & $\begin{array}{c}\text { Eksper } \\
\text { imen }\end{array}$ & $\begin{array}{l}3 \\
2\end{array}$ & $\begin{array}{l}0, \\
59\end{array}$ & 94 & $\begin{array}{c}0,7 \\
9\end{array}$ & 0,073 \\
\hline & $\begin{array}{c}\text { Kontro } \\
1\end{array}$ & $\begin{array}{l}3 \\
0\end{array}$ & $\begin{array}{c}0, \\
25\end{array}$ & $\begin{array}{l}0 . \\
75\end{array}$ & $\begin{array}{c}0,5 \\
3 \\
\end{array}$ & 0,095 \\
\hline
\end{tabular}

Berdasarkan tabel 3 di atas, rerata peningkatan kemampuan berpikir kritis matematis siswa yang pembelajarannya menggunakan model Project Based Learning memiliki kategori tinggi dengan nilai 0,79 lebih tinggi daripada siswa yang pembelajarannya secara konvensional berkategori sedang, yaitu 0,53.

Guna membuktikan bahwa nilai peningkatan kemampuan berpikir kritis matematis siswa kelas eksperimen lebih baik daripada kelas kontrol dilakukan uji perbedaan rerata nilai $N$-gain dengan menggunakan uji Independent Sample $T$ Test, karena data nilai $N$-gain berdistribusi normal dan homogen. Berikut rangkuman hasil uji perbedaan rerata skor $\mathrm{N}$-gain pada taraf signifikansi $\alpha=0,05$.

Tabel 4. Data Hasil Uji Perbedaan Rerata $N$-gain Kemampuan Berpikir Kritis Matematis

\begin{tabular}{|c|c|c|c|c|c|c|}
\hline \multirow{2}{*}{\multicolumn{2}{|c|}{ Skor }} & \multicolumn{2}{|c|}{$\begin{array}{c}\text { Levene's } \\
\text { Test for } \\
\text { Equalit } \\
\text { y of } \\
\text { Varianc } \\
\text { es }\end{array}$} & \multicolumn{3}{|c|}{$\begin{array}{l}\text { t-test for } \\
\text { Equality of } \\
\text { Means }\end{array}$} \\
\hline & & $\mathrm{F}$ & & & $\begin{array}{l}d \\
f\end{array}$ & $\begin{array}{l}\text { Sig. } \\
(1- \\
\text { taile } \\
\text { d) }\end{array}$ \\
\hline $\begin{array}{l}\text { N_Gai } \\
\text { n }\end{array}$ & $\begin{array}{l}\text { Equal } \\
\text { varianc } \\
\text { es } \\
\text { assume } \\
\text { d } \\
\end{array}$ & $\begin{array}{r}1.13 \\
9\end{array}$ & .290 & $\begin{array}{r}11.81 \\
2\end{array}$ & 60 & .000 \\
\hline
\end{tabular}

Berdasarkan tabel 4 di atas, uji perbedaan rerata $N$-gain diperoleh nilai sig.(1-tailed) adalah 0,000. Karena diperoleh sig. $(1$-tailed $)=0,000<0,05$ maka $\mathrm{H}_{0}$ ditolak. Artinya hipotesis diterima yaitu peningkatan kemampuan berpikir kritis matematis siswa yang pembelajarannya menggunakan model Project Based Learning lebih baik daripada peningkatan kemampuan berpikir kritis matematis siswa yang pembelajarannya secara konvensional. 


\section{KESIMPULAN DAN REKOMENDASI}

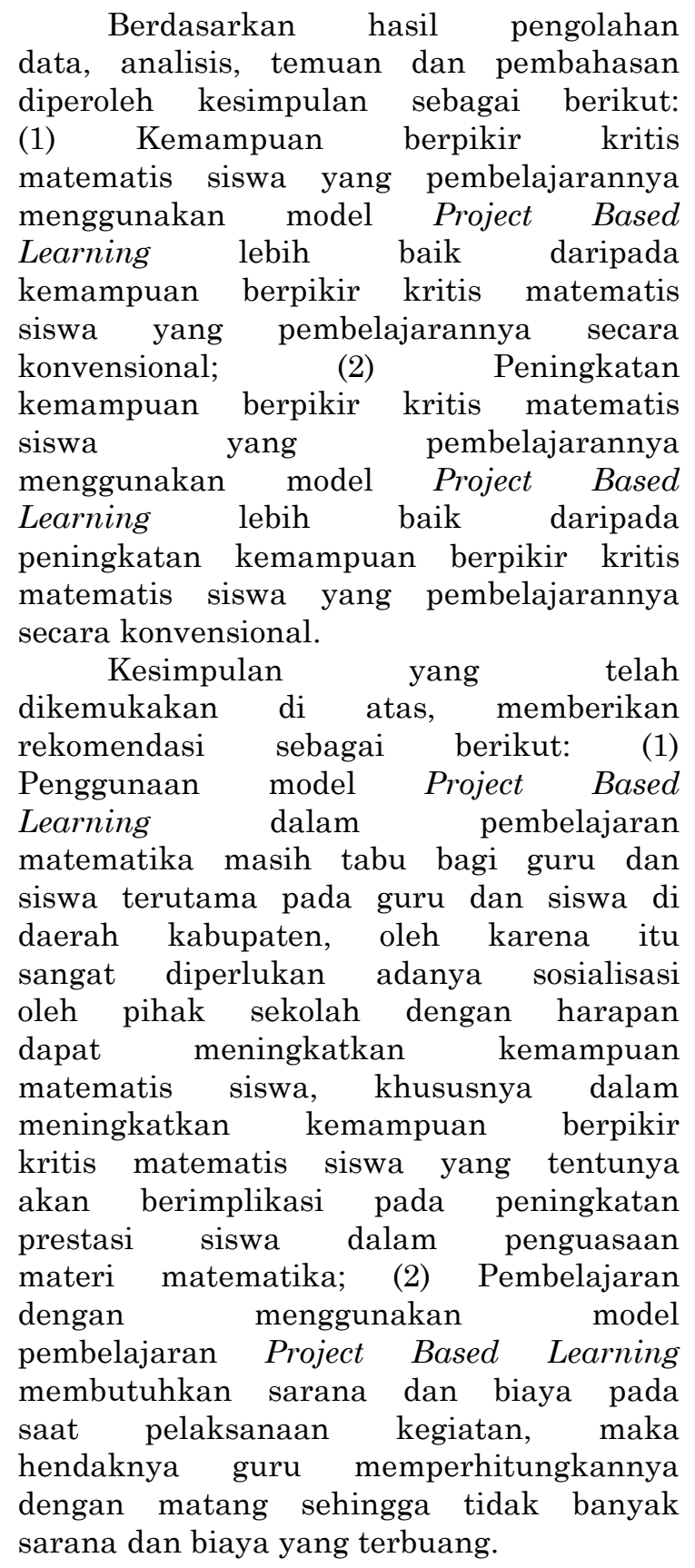

\section{DAFTAR PUSTAKA}

Hidayat, W. 2012. Meningkatkan Kemampuan Berpikir Kritis dan Kreatif Matematik Siswa Melalui Pembelajaran Kooperatif Think-TalkWrite /TTW (Studi Kuasi Eksperimen di kelas XI IPA SMA Negeri 2 Kota Cimahi. Tesis pada SPs UPI Bandung : Tidak Diterbitkan.
Kementrian Pendidikan dan Kebudayaan. 2013. Kompetensi Dasar Sekolah Menengah Pertama (SMP)/Madrasah Tsanawiyah (MTs). [online]. Tersedia: http://www.slidesshare.net/.../kurikulu m-2013-kompetensi-dasarsmp-ver-3-32013.pdf. [6 Maret 2015].

Kosasih, E. 2014. Strategi Belajar dan Pembelajaran (Implementasi Kurikulum 2013). Bandung: Yrama Widya.

Tafsir, dkk. 2008. Pengembangan Wawasan Profesi Guru (Bahan Ajar Pendidikan dan Latihan Profesi Guru/PLPG). Bandung. Fakultas Tarbiyah dan Keguruan UIN Sunan Gunung Djati Bandung.

Teguh, M. 2009. Guru Super Indonesia. Jakarta: Mario Teguh Publishing House.

TIMSS. 2007. International Mathematics Report: Findings from IEA's Trends in International Mathematics and Science Study at the Fourth and Eighth Grades. [Online].Tersedia:http://timss.bc.edu/ti mss2007/intl_reports.html.

Agustus 2015]. 